\title{
Ivana Slivková
}

\author{
Uniwersytet Preszowski (Słowacja) \\ University of Presov (Slovakia) \\ e-mail: ivana.slivkova@unipo.sk
}

https://orcid.org/0000-0002-6168-1327

\section{Светапогляд герояў у рамане Ігара \\ Бабкова Хвілінка. Тры гісторыі}

The worldview of the heroes in Ihar Babkov's novel "A Minute. Three Stories"

Światopogląd bohaterów powieści lhara Babkoua "Minutka. Trzy historie"

\section{Abstract}

This article provides a literary analysis and interpretation of Ihar Babkov's novel A Minute. Three Stories in the context of issues related to national identity and self-identification in Belarusian culture. The starting point of the author's deliberations is the theory of intercultural communication and the definition of cultural identity from a diachronic and contemporary point of view. The system of values presented in the novel is interpreted both in relation to the historical period and geographical area, and from the perspective of an individual involved in interpersonal relations and existing in a specific time and space. Although the dominant feature of the novel are the philosophical views and aesthetic principles professed by the protagonists, the indefinite and supranational dimension of time and space in the work allows for an interpretation in the context of cultural identity and identity in general (being a human means being...). The study is carried out using the comparative method, based on the theory of linguistic communication. The analysis proves that the plot of the novel is founded in the intertwining of different places and events, the concealing of the protagonists, and the combination of elements from both the real and the unreal. Further study showed that that one of the components of the Belarusian context in the novel is the philosophical pursuit of happiness by an individual in both a national and personal dimension.

Key words: Belarusian culture, Ihar Babkov, Three Stories, literary analysis, cultural identity

1 Артыкул 3'яўляецца часткай грантавага праекту: KEGA 051PU-4/2017 Slovník stredoeurópskych kultúr I (1790-1890). 


\begin{abstract}
Abstrakt
Artykuł został poświęcony analizie literackiej oraz interpretacji powieści Ihara Babkoua Minutka. Trzy historie w kontekście zagadnień związanych z tożsamością narodową i samoidentyfikacją jednostki w kulturze białoruskiej. Punktem wyjścia rozważań autorki jest teoria komunikacji interkulturowej oraz definicja tożsamości kulturowej w ujęciu diachronicznym i współczesnym. Przedstawiony w powieści system wartości interpretowano zarówno w odniesieniu do epoki historycznej i obszaru geograficznego, jak i z perspektywy historii człowieka uwikłanego $\mathrm{w}$ relacje interpersonalne oraz egzystującego $\mathrm{w}$ określonym czasie i przestrzeni. Chociaż dominantę literacką powieści stanowią poglądy filozoficzne i zasady estetyczne wyznawane przez bohaterów, to jednak czas i przestrzeń, posiadające w utworze wymiar nieokreślony i ponadnarodowy, pozwalają interpretować tekst przez pryzmat pojęcia tożsamości kulturowej i tożsamości w ogóle (być człowiekiem znaczy być...). Badanie zostało przeprowadzone metodą porównawczą, przy wykorzystaniu teorii komunikacji językowej. W wyniku analizy udowodniono, że fabuła powieści opiera się na splocie różnych miejsc i zdarzeń, mistyfikacji bohaterów oraz łączeniu elementów świata realnego i nierealnego. Ustalono także, że jednym z komponentów kontekstu białoruskiego w powieści jest filozoficzne poszukiwanie przez jednostkę szczęścia o wymiarze narodowym oraz indywidualnym.
\end{abstract}

Słowa kluczowe: kultura białoruska, Ihar Babkou, Minutka. Trzy historie, analiza literacka tożsamość kulturowa

\title{
Анатацыя
}

У артыкуле аналізуецца і інтэрпрэтуецца раман Ігара Бабкова Хвілінка. Tры гістоpbi $з$ пункту гледжання спецыфікі нацыянальнай ідэнтычнасці і самаідэнтыфікацыі ў беларускай культуры. Аўтарка зыходзіць 3 тэоры міжкультурнай камунікацыі, а таксама 3 гістарычных ідэалогій і жыццёвых праяваў культурнай ідэнтычнасці. Ідэйная аснова аповеду інтэрпрэтуецца не толькі як характарыстыка эпохі і краіны, але таксама як гісторыя чалавека (у часе і прасторы) і запавет чалавека чалавеку. Філасофскія і эстэтычныя прынцыпы, прэзентаваныя галоўнымі персанажамі, ствараюць дамінантную частку твора. Няпэўнасць і неакрэсленасць часу і прасторы ўтварае наднацыянальную лінію тэксту і абагульняе такім чынам прынцыпы нацыянальнай ідэнтычнасці ў напрамку ідэнтычнасці культурнай і ідэнтычнасці агульначалавечай (быщьь чалавекам - значыць быщь...). Выкарыстоўваюцца метады: літаратурная інтэрпрэтацыя, параўнанне, прымяненне тэорыі міжкультурнай камунікацыі. Вынікам інтэрпрэтацыі, сярод іншага, з’яўляецца факт, што перапляценне месцаў і часавых падзей, містыфікацыя персанажаў, змешванне рэальнага і нерэальнага ўтварае ў аповедзе базавую лінію. Далейшы аналіз паказвае, што культурнай спецыфікай беларускага кантэксту з'яўляецца філасофская канцэпцыя імкнення да нацыянальнага і асабістага шчасця.

Ключавыя словы: беларуская культура, Ігар Бабкоў, тры гісторыі, літаратурны аналіз, культурная ідэнтычнасць 
$\mathrm{P}$ азважанне над мастацкім тэкстам 3 пункту гледжання ўспрыняцця свету і яго характарыстык, а таксама канфрантацыі з уласным светам (як і погляд на яго) можна пачаць цытатай Ханса Георга Гадамера: „Тым, што мастацкі твор нешта гаворыць, ён канфрантуе чытача з самім сабой, г. зн., выказвае нешта, як паведамленне, і ўспрымаецца як раскрыццё, г. зн. як адкрыццё нечага схаванага" (Gadamer, 1999, s. 50). 3 прыведзеных слоў вынікае, што ў мастацкай літаратуры спалучаецца светабачанне аўтара, чытача і героя аповеду. Калі ж гэта трыяда належыць да аднолькавага нацыянальнага кантэксту і адначасова твор з'яўляецца рэфлексіяй над гісторыяй народа, прычым прасторай рэалізацыі дзеяння выступае цэнтр у выглядзе сталіцы, - літаратуразнаўчую інтэрпрэтацыю можна пашырыць адлюстраваннем гістарычных фактаў і культурнай спецыфікі, якія ўказваюць на асаблівасці аналізаванага кантэксту. Абапіраючыся на меркаванне Петэра Сондзі, што ў сучаснасці мы адчуваем дэфіцыт літаратурнай герменеўтыкі ў матэрыяльнай форме, г. зн. у практычнай інтэрпрэтацыі літаратурных тэкстаў, мы сканцэнтруемся на вышэй апісанай форме інтэрпрэтацыі сучаснага рамана ў беларускай мастацкай прасторы (Hlavatá, 2011, s. 99).

Раман Хвілінка. Tpы гісторыі Ігара Бабкова з пункту гледжання інтэрпрэтацыйнага патэнцыялу - надзвычай цікавы твор, які прапануе шматаспектныя магчымасці паглыблення ў тэкст і інтэрпрэтацыі яго зместу. Адным з такіх ракурсаў, які, на першы погляд, можа здавацца менш выразным, у параўнанні, напрыклад, з аналізам часу і прасторы, выступае светапогляд². Светапогляд як складнік спецыфікі нацыянальнай ідэнтычнасці і самаідэнтыфікацыі займае ўстойлівае месца не толькі ў беларускай культуры. У большасці характарыстык нацыянальнай культуры і ідэнтычнасці, падобна як у тэорыі нацыянальных і этнічных стэрэатыпаў³, выяўляецца філасафічнасць / філасофскае разважанне / філасофскае ўспрыманне рэальнасці як адна з рысаў беларускай культурнай ідэнтычнасці. Паводле тэорыі міжкультурнай камунікацыі нацыянальныя стэрэатыпы з'яўляюцца такім устойлівым складнікам культуры, што іх пазіцыя параўнальная з пазіцыяй вуснай народнай творчасці (што істотна паўплывала на фарміраванне беларускай і славацкай мастацкіх літаратур і літаратурных моў4). Такія культурныя стэрэатыпы ўзнікаюць на аснове энкультурацыі і сацыялізацыі, іх можна разумець як пэўныя формы міфаў і сімвалаў. Вялікую ролю ў пашырэнні стэрэатыпаў, акрамя перадачы традыцыі з пакалення на пакалення, мае і непасрэднае назіранне,

2 Светапогляд - гэта сукупнасць філасофскіх, рэлігійных, палітычных, этычных, прыродазнаўчых і інш. поглядаў, паняццяў, уяўленняў пра навакольны свет (Krátky slovník slovenského jazyka 4).

3 Этнічны стэрэатып - ацэнка прадстаўнікоў пэўнага народа паводле комплексных стэрэатыпных прыкмет.

4 Тыпалагічнае падабенства ўплыву празаічнага фальклору на беларускую і славацкую літаратурныя мовы праз пасрэдніцтва нацыянальнай мастацкай літаратуры выявіла і прасачыла Вікторыя Ляшук у навуковай манаграфіі Фальклорны вектар у кадыьфікацыі беларускай і славачкай моў (Liashuk, 2009). 
a ў сучасны перыяд таксама і ўплыў медыйных сродкаў5. Такім чынам’ укаранёныя стэрэатыпы (кадыфікаваныя - паводле Košt’álová, 2012) часта выкарыстоўваюцца пры высвятленні так званых культурных кодаў, якія характарызуюць канкрэтную культуру. Нацыянальныя стэрэатыпы, якія могуць быць параўнаны 3 пазіцыяй так званай народнай міфалогіi, утвараюць пэўны складнік культурнага кантэксту, які прэзентуецца ў напрамку да сябе, гэта значыць, выхоўвае і адукоўвае прадстаўнікоў уласнай культуры, і адначасова акцэнтуе нацыянальную спецыфіку знешне, у напрамку да носьбітаў іншых культур - гэта значыць, адрознівае, параўноўвае. Апазіцыя свой - чужы ў літаратурнай прасторы зусім не навінка, а ў тых нацыянальных кантэкстах, якія развіваюцца пад узмоцненым уплывам іншай культуры, гэта тыповая з'ява. Пару наш і не наш можна ў аднолькавай ступені, як у беларускім літаратурным (і культурным) кантэксце перанесці i на славацкую прастору (напрыклад, апазіцыя чэшскі vs. славацккі і інш.).

Культурныя супольнасці кіруюцца пэўнымі схемамі, пабудаванымі на сістэме канкрэтных формаў паводзін дадзенай супольнасці. Да іх належаць, напрыклад, каштоўнасная і маральная арыентацыя, законы, традыцыі, сацыяльныя табу і г.д. Акрамя таго і культурныя ўзоры выступаюць складнікам культурнай ідэнтычнасці як усведамлення прыналежнасці да пэўнай культуры і згоды 3 чаканнямі, якія мае ўласнае асяроддзе. Культурная ідэнтычнасць адначасова ўтварае калектыўную ідэнтычнасць, якая аб'ядноўвае асобу і калектыў (перайманне канкрэтных сацыяльных і культурных характарыстык). Яна фарміруецца паступова, развіваецца і лепш за ўсё ідэнтыфікуецца у сутыкненні з чужой культурай.

Сістэма каштоўнасцей чалавека з'яўляецца індывідуальнай катэгорыяй, суб'ектыўнасць якой папярэдне зададзеная, і адначасова зменлівая пад уплывам шматлікіх фактараў - напрыклад, пашырэння сацыяльных роляў чалавека, пад уплывам пазнання комплекснага вопыту і г.д. Аксіялогія выступае важным складнікам чытацкага ўражання, прычым так як двое людзей не зразумеюць ідэнтычным чынам адну метафару, так і ўспрыманне светапоглядных пытанняў будзе адрознівацца ў любым - напрыклад, намі выбраным - тэксце. Сваю ролю ў гэтым грае не толькі нацыянальная прыналежнасць чытача, але і шматлікія іншыя фактары, такія, напрыклад, як веданне беларускага літаратурнага, а таксама шырэйшага гістарычнага і грамадскага кантэксту.

У аналізаваным тэксце, як і ва ўсім беларускім літаратурным кантэксце, істотна тое, што кантакт з замежнымі літаратурамі выступае для гэтай нацыянальнай літаратуры адной з падстаў аптымальнага развіцця 6 . Таму ў прасторы

5 Тыповым стэрэатыпным уяўленнем пра беларусаў, якое распаўсюджваюць сучасныя масмедыя, выступае праблематычная палітычная сітуацыя і нестабільнасць у выкарыстанні дзяржаўнай мовы (у Беларусі статус дзяржаўнай маюць беларуская і руская мовы).

6 Падобнае мысленне заўважаецца ўжо ў спробах тэарэтычнага асэнсавання беларускай літаратурнай творчасці ў працах Максіма Багдановіча. 
інтэрпрэтацыі мы ўлічваем не толькі адмежаванне беларускай літаратуры ад рускай ці польскай, але і яе суаднясенне са славянскай літаратурнай прасторай7.

Гісторыю Хвілінкі вельмі цяжка дакладна акрэсліць у часе і прасторы, адзіным дапаможным для інтэрпрэтацы элементам выступае катэгорыя персанажа. Хвілінка - нетыповы раман $з$ лінейным дзеяннем. Ён змяшчае тры ў пэўнай меры самастойныя гісторыі, якія разгортваюцца ў трох раздзелах: Партрэт мастака, нябачны у сутонні; Паветраны шар; Гексаграма сун: супчык са шпінату. 3 аднаго боку, іх аб'ядноўвае асоба апавядальніка як непасрэднага ўдзельніка падзей, з другога боку, тры героя - паэт Францішак, апазіцыйны актывіст Багдан і спявачка Эва Дамініка. Рамкамі хранатопу выступае мінская кавярня „Хвілінка”. У канцы 80-х гадоў галоўныя персанажы сустракаліся у ёй адзін з адным і з містычным барменам Леа, які ў рамане адыгрывае важную ролю; метафізічным спосабам усе яны тут застаюцца. Акрамя таго трэба браць пад ўвагу перакрыжоўванне элементаў хранатопу, а таксама заблытванне эпізоднымі адхіленнямі сюжэтнай лініі тэксту. Разам з тым у „Хвілінцы” „працінаюцца позіркам сцены i эпохі” (Babkou, 2013, s. 9), і гэта надае пэўную ўстойлівасць разгледжаным намі уяўленням пра навакольны свет. Нарадзіўшыся „ў гэтым часе і гэтым месцы” (Babkou, 2013, s. 9), персанаж Францішка, дзякуючы аўтарскаму намеру, можа сказаць шмат і ў той жа час не сказаць нічога адкрыта. У гэтую малую кавярню ўсе ішлі з неакрэсленым намерам, а таму ў ёй кожны мог знайсці сваё. Адно шукаў апавядальнік (шукаў сваю гісторыю і адпаведную паставу), другое - Францішак, іншае - Багдан ці Эва Дамініка. Трэба таксама заўважыць, што вяртанне ў „Хвілінку” ніколі не было паўтарэннем, ды і матывацыя пошукаў мяняецца - ад двайной кавы праз пошук мудрасці і праўды аж да кульмінацыі спадзяванняў і амбіцый - літаратурных, грамадска-палітычных, пачуццёвых. Камерцыйны характар горада таксама ўключаецца ў фарміраванне светапогляду - трэба выбраць адну з кавярняў, выбраць сабе месца, напой, кампанію, і гэта значыць, што ва ўсім і заўсёды мы маем магчымасць выбару. Як піша аўтар: гэта прадчуванне магчымасці, спроба зрабіць выбар і месца (разумей - ка́са ў кавярні), дзе трэба за ўсё заплаціць. А таму абставіны, гарады, месцы і гэтак далей у гісторыі вельмі туманныя, таму мы чытаем аб „адным 3 месцаў, у адным з гарадоў” (Babkou, 2013, s. 15), пра пошукі ў іншых жыццях (пошукі натхнення і праўды), пра памнажэнне рэчаіснасці, пра тое, што ўсё „далей трэба было разгадваць, расшыфроўваць: што адбылося, чаму” (Babkou, 2013, s. 19).

Тэматычна і ідэйна раман ахоплівае шматлікія пласты: метафізічную існасць чалавека і яе прадвызначанасць, адзіноту, палітыку (са спасылкамі на рэальныя палітычныя працэсы ў Беларусі), праблему мовы і творчасці, а таксама каханне ў форме любоўнага трохкутніка.

Як перакладчыца раману Хвілінка на славацкую мову я лічу пашырэнне поля інтэрпрэтацыі за кошт славацкага кантэксту цалкам натуральным, як і даследаванне трансферу беларускіх элементаў у мэтавую мову. 
Кожны 3 трох апісаных у гісторыі персанажаў мае сваю культурную адметнасць. Францішак - як паэт, што піша па-беларуску - адсуджаны на няўдачу, ён увасабляе сабой героя, які адлюстроўвае ў сваіх паводзінах пэўныя грамадскія змены (спачатку пісанне па-руску, потым па-беларуску, далей маўчанне і нарэшце стварэнне „бунтоўных” тэкстаў). Калі зыходзіць з прынцыпа, што паэзія - душа народа, то Францішак - прамоўца, які тлумачыць свету сутнасць духоўнага ў культуры. У тэксце можна сустрэцца $з$ яшчэ больш смелым меркаваннем, накшталт: паэт як увасабленне быцця, стваральнік рэальнасці і г. д. Тыповай эмоцыяй у Францішка 3'яўляецца неспакой, а тыповай дзейнасцю - чаканне / прадчуванне/прадбачанне - „Паэзія - адзін з самых небяспечных заняткаў, сказаў ён. Асабліва для тых, хто патрапіў усярэдзіну. I таму тыя, хто прадчувае глыбіні, ведаюць, як няпроста быць лёгкімі. I цэняць гэта.” (Babkou, 2013, s. 57). Да універсальных рысаў паэтаў належаць таксама яго несамавітасць (імкненне гаварыць інакш, чым усе), сон наяве (з расплюшчанымі вачыма) і звязаная з гэтым праблематызацыя фактаў (жыць можна і без неабходных праўдаў і нават лепш). Аднак, калі Бабкоў піша пра паэтаў, то гаворыць і пра нейкую „этнічную секту", пра рэвалюцыі і барыкады, пра крытыку грамадства і пра паразу. Паэзію ён характарызуе як адну з самых небяспечных рэчаў на свеце - зразумела, для тых, хто пранік ў яе сутнасць. На першым плане, такім чынам, мы бачым паэта Францішка, які ўчыніў культурнае самазабойства і сам сябе асудзіў на няўдачу, прыняўшы рашэнне, што будзе пісаць па-беларуску; паэт, які выбраў паразу замест ўдачы. Выбраў для сябе паэтычную культуру, у якой большасць тэкстаў ідэальна патрапляе ў хрэстаматыю для дзетак-беларусаў - мілыя, цудоўныя, простыя словы, што гавораць пра простыя рэчы. (Babkou, 2013, s. 56). 3 іншага боку, чытач хоць і не бачыць, але адчувае ў ім адукаванага чалавека, які ўсведамляе небяспеку пазнання і бачыць глыбіню жыцця ў яго зменах. Знаёміцца з крытыкам і вечна незадаволеным рэвалюцыянерам, катэгарычнасць і просталінейнасць якога бывае часам непрыемнай:

Апошняе беларускае адраджэнне, напісаў ён, пачыналася як рыцарскі гэст, як абарона пакрыўджаных. Памерлых, закатаваных, забытых. А скончылася правым праектам, ідэалагічнай абслугай перыферыйнага капіталізму. Чаму так адбылося, няясна. Але тое, што ясна і пэўна - у кожнага цяпер свая сцежка і свая праўда (Babkou, 2013, s. 68).

Як піша Нора Краўсава, кожнае чалавечае пазнанне з'яўляецца гнасеалагічным актам, гнасеалагічным адлюстраваннем, 3 гэтага гнасеалагічнага адлюстравання аўтар робіць эстэтычны выбар, надае рубяжы і межы гэтай реальнасці (Krausová, 1984, s. 21). Такім чынам, ствараецца персанаж, які адлюстроўвае рэчасінасць праз свай характар, а таксама сваімі ўчынкамі, як у выпадку з Францішкам, i, безумоўна, сваім поглядам на свет. Гэтыя ўласцівасці светапогляду складаюць аснову эстэтычнай функцыі аналізаванага тэксту і адначасова нясуць у сабе закадаваную інфармацыю наконт характару „разважнага, здатнага да філа- 
сафавання" беларуса, гэта значыць пра нацыянальную рысу, якая атрымала асэнсаванне ў культурным стандарце.

Асоба Багдана - носьбіт зусім іншых характарыстык. Гаворка ідзе пра вельмі канкрэтнага персанажа - уведзенага ў канкрэтны час і прастору, якія мадэлююць прататып барацьбіта. Гэта заснавальнік суполкі прыхільнікаў беларускай гісторыі, вельмі актыўны і ангажаваны ў грамадска-палітычным жыцці. Ён змагаецца за новую будучыню, i, адначасова, за аднаўленне традыцый мінулага (сцяг, герб, Купалле). 3 іншага пункту гледжання, гэты герой выразны менавіта сваёй невыразнасцю: спачатку за ім ідуць масы, ім захапляюцца, яго падтрымліваюць (усе, хто лічыць краіну сваёй), але паступова ён становіцца толькі ўспамінам, губляецца ў імгле мінулага. У гісторыю ён прыўносіць вельмі важныя элементы - нелегальныя суполкі, рэвалюцыйнасць, актыўнасць, традыцыі, моўныя і перакладчыцкія пытанні, палітычныя і грамадскія характарыстыкі. Разам з тым, фрагмент Багданавай гісторыі ў раздзеле Паветраны шар - найбольш зразумелая, мабыць, частка кнігі для чытачоў. Ягоны пошук адпачынку, кароткі прыпынак у актыўнай, грамадска карыснай працы - гэта вяртанне да сябе самога. Асабістае шчасце і спакой даюць толькі ўспаміны (піянерскі лагер, загадкавая купалінка). Насуперак таму, што ён увесь час нястомна працуе дзеля грамадскай карысці, дзеля новай і прыгажэйшай будучыні, сапраўднае задавальненне і пазітыўныя пачуцці даюць толькі ўспаміны, якія пераносяць Багдана ў часе і дазваляюць зрабіць прагматычнае адкрыццё, што „ўсё ўжо адбылося”. Светапогляд персанажа адлюстроўваецца праз яго палітычную дзейнасць, дзякуючы чаму чытач атрымлівае мноства займальных звестак пра функцыянаванне краіны, пра палітычныя кампаніi, пра дзейнасць міліцыі, пра выйгрышы і пройгрышы, пра магілы без імён, герояў і ворагаў.

Гістарычны гарызонт тэксту заўсёды перакрыжоўваецца 3 наяўным і індывідуальным гарызонтам чытацкага чакання (Hlavatá, 2011, s. 96). Даўжэйшы часавы інтэрвал звычайна дапамагае зразумець гістарычныя падзеі, а таксама іх магчымыя вынікі у сучасным грамадстве. Асоба Багдана выступае носьбітам двух памкненняў - барацьбы за нацыянальную гісторыю і пошукаў асабістага шчасця. Абодва матывы злучаюцца ў т. зв. варшаўскім эпізодзе аповеду. Злучэнне гэтых двух Багданаў/двух Багданавых светаў - палітычнай актыўнасці і пошуку асабістага шчасця - апісваецца праз інтэрпрэтацыю верша Баляслава Лесьмяна Дзяўчына. У ім бачым, як разбурэнне муру дзеля міфічнага голасу (разумей: барацьба за лепшую будучыню Беларусі) вядзе да свабоды, ды толькі часовай i, як ні парадаксальна, стварае новыя муры і прыводзіць да трагічнага фіналу, таму што кожны паддаўся ўласным памкненням і снам і перастаў змагацца за сумесны сон (свабодную краіну). Падобная думка развіваецца і ў варшаўскім эпізодзе Багданавай гісторыі. Там ён сустракаецца са старым прафесарам паліталогіi, які, акрамя ўсяго іншага, сцвярджае дзве істотныя рэчы. Па-першае, што палітыка стварае і вырошчвае штучны свет, які існуе ва ўяўленнях звычайных людзей, прычым „у самай паспалітай, нізкай, часам нават агіднай форме” (Babkou, 2013, s. 142). I, па-другое, 
што дэмакратыя існуе толькі для багатых. Ад гэтага Багданава адчуванне бессэнсоўнасці ягоных дзеянняў ў імя будучыні краіны толькі паглыбляецца, і на першае месца выходзіць пошук асабістага шчасця: „Раптоўна ён адчуў спакой і цішыню ўнутры сябе. Як быццам бы хтосьці прыйшоў у пакой і нарэшце выключыў радыё, якое гучала так доўга і так гучна" (Babkou, 2013, s. 163).

Паводле Гадамера, мастацкі твор, які скіраваны да мінулага і пераносіць у нашу прастору гістарычна аддалены свет, не мае ў пэўнай культавай альбо грамадскай галіне вызначальнай функцыі, але становіцца звычайным прадметам гістарызаванага ўражання; эстэтычная каштоўнасць твора залежыць ад структурных заканамернасцей, якія дазваляюць твору выйсці за рамкі гістарычна абмежаванага часу свайго ўзнікнення або дадзены культурны кантэкст (Hlavatá, 2011, s. 96). Менавіта пераадоленне межаў культурнага кантэксту на прыкладзе лёсу Багдана (як палітычнага актывіста, як нацыянальнага гісторыка, як прадстаўніка ў польскім асяроддзі „народа ў небяспецы” і г.д.), дапаўняе мазаічную характарыстыку светапогляду беларусаў яшчэ адным важным аспектам.

Трэцяй асобай у гісторыі выступае таямнічая Эва Дамініка. Гэта маладая студэнтка, якая маючы выдатную кар'ерную перспектыву опернай дзівы, выбрала сціплую суполку і прысвячае сябе беларускаму фальклору і захаванню традыцый. Эва Дамініка - прыгожая, мае арыстакратычнае паходжанне і таксама далучае да гісторыі сваё звяно мінуласці - эпізод пра настаўніка, які знікае ў дрыгве 3 цэлым выпускным класам і вартаецца праз гады. Роля Эвы Дамінікі істотная для сустрэчы ў інтэрнаце, дзе сустракаюцца ўсе тры персанажы - гэта звяно паміж Францішкам і Багданам, гэта падключэнне да беларускай традыцыі і мінуласці, гэта femme fatale, гэта сведка падзеяў, гэта менавіта тая, хто паверыць у магчымасць уцёкаў паветраным шарам... I гэта менавіта яна разам з героямі згодзіцца на новую і найцяжэйшую ролю - стаць стваральнікамі новага свету, як богі: „мы змагаемся з драконамі, мурашамі і беларускай доляй. Усё пачынаем нанова" (Babkou, 2013, s. 198).

Дзейснай формай чалавечай ідэнтыфікацыі і камунікацыі ў літаратуры выступае аповед. Ён базуецца на каўзальнасці, канфлікце, завершанасці, прычынна-часавай паслядоўнасці. Ад раманаў чытач чакае гульні 3 фантазіяй, але ж і апавядальнасці, а таксама паказання пэўных прыкладаў чалавечых паводзін. На паводзіны і свядомасць чалавека ўплывае мноства фактараў, якія пашыраюць межы выяўлення і ўспрымання. Тры персанажы ўяўляюць сабой тры тыпы характараў і павінны былі б прэзентаваць носьбітаў адпаведнай культуры. Напачатку сустрэчы яны адрэкамендуюцца як арыенталіст-аматар (Францішак), зусім невядомая спявачка (Эва Дамініка) і проста герой (Багдан). Паэт, фальклорная спявачка ды гісторык/палітык. Гэта носьбіты сацыяльных роляў, цесна звязаных з беларускімі рэаліямі і традыцыямі. Паэт Францішак піша па-беларуску, Эва Дамініка - нашчадак беларускага арыстакратычнага роду і захавальніца беларускіх традыцый, а Багдан адштурхоўваецца ад гістарычных звестак пра вялікі і свабодны беларускі народ, каб змагацца на палітычнай сцэне за 
шчаслівую будучыню Беларусі. Кожны з персанажаў, такім чынам, нацыянальна свядомы, кожны змагаецца за свабоду выяўлення і кожны - незадаволены, імпульсіўны ў пошуках і ў пэўнай ступені няшчасны. Парадаксальным чынам усе яны процістаяць большасці і, значыць, прэзентуюць нетыповага, прыналежнага да меншасці, беларуса. Іх самаідэнтыфікацыя будуецца на кантрасце з рэчаіснасцю, на тым, што насуперак свайму імкненню захоўваць важныя нацыянальныя каштоўнасці, яны апынаюцца на перыферыі грамадства (дакладней, канкрэтнага калектыву). Таму аўтарскую задуму можна інтэрпрэтаваць з розных пунктаў гледжання (крытыка большасці грамадства, абарона меншасці, пасіўнасць vs. актыўнасць, выгада на шкоду страты і г.д.).

Магчымым адказам на ўчынкі персанажаў і кульмінацыяй гісторыі з'яўляецца заключнае прароцтва: „Малады кароль памірае і нараджаецца зноў. Маг знаходзіць крыніцы сілы. Каралева вяртаецца на трон” (Babkou, 2013, s. 229). Кожны з герояў вяртаецца ў свет, дзе змагаецца ў асабістых бітвах і атрымлівае тое, што заслужыў. Карты раздадзены, і гульня зноў можа пачынацца. Персанажы ў рамане Ігара Бабкова тыпалагічна розныя, хоць кожны з іх прэзентуе спецыфіку светапогляду 3 падобнай культурнай базай. Наднацыянальны характар твора заключаецца ў абагульненай ідэі, якой выступае пошук асабістага шчасця, рэалізаванага ў розных формах.

У нашым аналізе мы зусім выпусцілі з-пад увагі постаць бармена Лео, які 3'яўляецца выразным тыпам духоўнага правадыра. Ён пастаянны і адначасова зменлевы (адпаведна з эпохай). Рэпрэзентуючы традыцыю, пазнанне і мудрасць у чыстым выглядзе, ён бесстаронні і адначасова ён нехта накшталт асабістага гуру для кожнага $з$ наведвальнікаў кавярні „Хвілінка”. Ён робіць абагульненне ўсіх памкненняў у заўвазе, што свет - заўсёды аднолькавы, і „чалавечы кон частковасць" (Babkou, 2013, s. 225). У чатырох гісторыях пра прынца ён прапануе варыянты погляду на свет і абыходжання са сваім лёсам: здабыць пазнанне пры ўмове, што цаной будзе забыццё; змагацца і пры гэтым страчваць; атрымаць сапраўдную каштоўнасць у выглядзе кахання, але страціць славу і прызнанне; марыць і быць у пошуку, але нічога не атрымаць назаўсёды (бо самі мары і пошукі і ёсць здабыткам).

Не меней істотным з'яўляецца факт, што за вокнамі кавярні „Хвілінка” нязменна пануе восень. Восень - пара выспявання, а таксама час перад адпачынкам (напрыклад, прыроды, чалавека ў старасці), ды яшчэ яна адначасова каляровая і сівая - на наш суб'ектыўны погляд. Гэта час, калі ў апошнюю хвіліну адбываецца нешта істотнае: „Час сканчаецца заўсёды раптам. Яшчэ перад гэтым яго так многа, але вось яшчэ хвіліна і ты разумееш: часу больш няма. Разумееш, што сапраўды позна. Калі позна, калі ўжо няма часу, калі застаецца толькі хвілінка, тады ўсё адбываецца" (Babkou, 2013, s. 94).

Крытыкі лічаць, што Хвілінка ў вялікай ступені прэзентуе традыцыі магічнага рэалізму. Зыходзячы з формаў выяўлення, вядомых з твораў Маркеса, Борхеса ці Картазара, аўтар прапануе чытачу партрэт тыпізаванага беларуса ў нетыпо- 
вых праявах. Акрамя таго, Ігар Бабкоў мае выключныя здольнасці апавядальніка, а ўжываючы шматлікія спасылкі на кітайскую і антычную філасофію, на філасофію Вітгенштэйна, экзістэнцыялізм Сартра або літаратурны мадэрнізм, ён раскрывае свой шырокі інтэлектуальны кругагляд і адначасова выказвае давер чытачу - яго творчай здольнасці зразумець складаны тэкст.

Светапогляд у Бабкова заснаваны на пошуку і нястомнай незадаволенасці актуальным станам рэчаіснасці (што ёсць і што будзе), гэта таксама пазнанне мудрасці (гісторыя і філасофія як складнікі пазнання - што было і што будзе), і галоўнае - гэта назіранні: ніякія факты не даюць адказу, адказ дае толькі летуценне, фантазія, уяўленне, прароцтва. Няма сумнення, што раман распавядае пра Беларусь і асэнсоўвае беларускую культурную ідэнтычнасць, яе культурныя коды. У тэксце знаходзіцца мноства знакавых элементаў, якія апісваюць постсавецкую эпоху, змаганне за незалежнасць і родную мову. Парадаксальна, але якраз тое, чым Беларусь павінна ад іншых краін адрознівацца, аб'ядноўвае яе 3 мноствам іншых краін. Хіба для іншага народа гісторыя і традыцыя неістотныя? Хіба іншыя не шукаюць шчасця, спадзеючыся на тое, што яно прыйдзе ў будучыні, пры гэтым не заўважаючы таго, што ўжо маюць? Хіба ўлада не належыць багатым, і за правільнае не лічыцца тое, чаму аддае перавагу большасць? Хіба на чале пратэстаў не стаяць творцы і летуценнікі з фантазіяй? Хіба іншыя краіны лепей далі рады 3 надыйшоўшай свабодай?

Літаратура павінна казаць праўду і зрываць маскі. У такім выпадку можна сказаць, што светапогляд ў творы Ігара Бабкова - гэта погляд у люстэрка. Кожны чалавек „толькі вучыцца быць чалавекам. Ён заўсёды ў дарозе. I дарога заўсёды ў iм" (Babkou, 2013, s. 193).

Літаратура XX стагоддзя ў яе розных фазах фармавалася дынамікай эвалюцыйных і рэвалюцыйных змен, эстэтычным ўспрыманнем новай гістарычнай эпохі. Адной з галоўных прыкмет выступае разуменне літаратуры як пэўнага нацыянальнага і гістарычнага тыпу мастацкай творчасці, гэта значыць падкрэсліваецца яе сувязь 3 традыцыяй (гл. Gál, 2014, s. 387). 3 іншага боку, на яе развіццё ўплываюць не толькі грамадскія змены, але і ўнутраныя працэсы, што вызначаюць яе перыядызацыю. Хуткія змены плыняў, напрамкаў або тэндэнцый, якія ў большай ці меншай меры былі звязаны з эстэтычна-мастацкім кантэкстам эпохі, прынеслі новыя магчымасці аўтарам і чытачам. Магчымасці бачыць свет, успрымаць і адлюстроўваць яго ў адпаведнасці з уласнымі поглядамі. 


\section{Bibliografia}

\section{Źródla}

Babkou, Ihar. (2013). Chwilinka. Try historyiji. Minsk: Lohwinau. [Бабкоў, Ігар. (2013). Хвілінка. Тры гісторыі. Мінск: Логвінаў].

Krátky slovník slovenského jazyka 4 (2003). Pobrano z: http://www.juls.savba.sk/kssj_4.html (dostęp: 15.03.2018).

\section{Opracowania}

Gál, Slavomír. (2014). Ukrajinská literatúra v dvadsiatom storočí. In: Ivana Hostová (ed.). Vývinové problémy svetovej literatúry 20. storočia. Príspevky $k$ dejinám britskej, americkej, nemeckej, talianskej, francúzskej, pol'skej a ukrajinskej literatúry (s. 387-409). Prešov: Filozofická fakulta Prešovskej univerzity v Prešove.

Gadamer, Hans-George. (1999). Člověk a rěč. (Výber textů). Praha: OIKOYMENH.

Hlavatá, Renáta. (2011). Fenomén historizmu v myslení o literatúre. Nitra: Filozofická fakulta UKF v Nitre.

Koštálová, Petra. (2012). Stereotypní obrazy a etnické mýty. Kultúrní identita Armenie. Praha: SLON.

Krausová, Nora. (1984). Význam tvaru - tvar významu. Bratislava: Slovenský spisovatel'.

Liashuk, Viktória. (2009). Folklórny vektor v kodifikácii bieloruského a slovenského jazyka. Prešov: Filozofická fakulta Prešovskej univerzity.

Slivková, Ivana. (2015). Úvod do interkultúrnej komunikácie. Prešov: Vydavatel'stvo Prešovskej univerzity.

Data nadesłania artykułu: 19.04.2018 